\title{
User and Library Failures in an Undergraduate Library
}

\begin{abstract}
A survey was conducted in the undergraduate library at the University of Tennessee, Knoxville, to determine the availability rate of library materials. The library administration felt that a low rate of availability could mean that a major service deficiency existed. The results indicated that 53.8 percent of the titles searched were located on the shelf in the library. A breakdown of the reasons for failure and recommendations for improvements are presented.
\end{abstract}

\begin{abstract}
As librarians everywhere sit comfortably reading the literature of their profession and reflecting on their libraries' achievements, patrons may be leaving those libraries after having found an average of only half the books they have sought on the shelves. A frustration that is frequently expressed about libraries is that the books the user needs are not available at the time they are needed.

Daniel Gore contended in the twentyseventh University of Tennessee Library Lecture that ". . . a small portion of any library collection is in such heavy demand that the books are often unavailable when wanted-so often that the average rate of unavailability for all wanted books owned by an academic library appears to be in the range of 50 percent." 1

Such assertions have led some librarians to try to determine how successful their library has been in making materials available for the library user. The title given to such an investigation is an "availability study," because it seeks to determine to what extent books are available when sought. Gore defined an availability rate as "the percent of wanted books held by the library that are available on your shelves when your patrons want them." 2
\end{abstract}

Rita Hoyt Smith is reference librarian, undergraduate library, and Warner Granade is business reference librarian, main library, University of Tennessee, Knoxville.
How well does the University of Tennessee undergraduate library meet user demands? The collection at the John C. Hodges Undergraduate Library is made up of approximately 160,000 volumes, selected to support courses taught at the undergraduate level and to stimulate the recreational and cultural reading interests of undergraduate students. It is one branch in a system of six campus libraries that also includes the main library and the libraries of agriculture-veterinary medicine, law, music, and science-engineering. A separate undergraduate collection at the University of Tennessee was activated in 1959, and a separate building was opened in 1969.

Does the undergraduate library's specialized nature and multiple-copy policy assure a greater availability rate than the 50percent average that Gore alluded to in his lecture? Librarians hope that their library can provide significantly more than 50 percent of the items sought. But suppose that the unavailability rate does approach 50 percent. What are the factors that would contribute to such failures? What percent is a result of high demand, of library malfunction, and of user error? In response to these questions and concerns, the administration in the Hodges Undergraduate Library began to investigate the literature to see what other libraries were finding.

\section{Previous WORK}

A review of the literature from the past ten years revealed a rather small number of studies, conducted in the United States and 
Great Britain, investigating the availability of library materials. Most have reported 40-percent to 50-percent failure rates among library patrons. Michael Buckland noted that, through attention to availability rates and through measures taken subsequently by the University of Lancaster, the library there was able to raise the satisfaction rate among its patrons from 60 percent to 86 percent. ${ }^{3}$ Buckland was particularly interested in changes that could be effected through modified loan and duplication policies.

J. A. Urquhart and J. L. Schofield began conducting availability studies in the late 1960 s through the Library Management Research Unit (LMRU) at the Cambridge University Library. Reporting on studies in different types of academic libraries, LMRU found that library A (one library serving an entire academic community) had a failure rate of 49 percent; library B (a main library in a system with departmental libraries) had a failure rate of 40 percent; and library C (a departmental library serving one faculty) a failure rate of 39 percent. ${ }^{4}$

Schofield, Cooper, and Waters reported a failure rate of 44 percent in the main collection of an academic library that had a circulation period of two weeks. The same library's short-loan collection, which had a circulation period of four days, had a failure rate of 31 percent. ${ }^{5}$ Urquhart and Schofield contended that the results of an availability study could be used to justify budget requests, to establish priorities for procedural changes, to specify titles and subject areas in great demand, and to suggest patterns of reader behavior.

Intrigued by these British studies and by Richard Trueswell's work with circulation data, ${ }^{6}$ Gore raised the issue of the availability problem for libraries in the United States. Incredulous of statistics reporting 40-percent to 50-percent failure rates in the library, he conducted an availability study in his library at Macalester College and was shocked to find a 42percent failure rate there. ${ }^{7}$ Gore believes that these kinds of statistics pose serious problems for library management and that more attention needs to be directed toward formulation of effective acquisition and loan policies.
The latest reported study was conducted by Saracevic, Shaw, and Kantor at Case Western Reserve University. ${ }^{8}$ Two surveys were taken, one before and one after a change in the library's circulation policy from semester loan to four-week loan. The surveys set out to measure the performance of both the library and the user. In the first study, conducted before the loan period was changed, the failure rate at its peak was $\mathbf{5 2}$ percent. In the second study, after the change, the failure rate at its peak was 44 percent. The investigators were satisfied that the change in the loan period had improved the performance of the library, while noting that other factors were also involved. User error in both studies was high enough for them to recommend improved graphics and orientation. Due to the high number of missing books, they also recommended an improved security system.

\section{INITIAL INVESTIGATION}

During the fall quarter 1975, the Hodges Undergraduate Library administration decided to conduct an availability study. The purpose of the study was to determine if patrons were finding what they wanted through the card catalog; if there was significant failure locating books on the shelves; and if there were specific titles or general fields of information in high demand. From the information generated by the study, the administration expected an analysis of the reasons for failure to provide needed materials at the catalog and on the shelves. Other expected results included input for a materials selection policy and assessments of the points of weakness in the collection, of the viability of the circulation period, and of other service activities such as library instruction and patron assistance.

When all the data were collected and analyzed, it became obvious that a rate of availability/unavailability could not be calculated. This was due to the construction of the survey form, which allowed for a simple yes or no answer to the questions, "Did you find the books you were looking for in the card catalog?" and "Was the book you wanted on the shelf?" The major objective of the study had been to determine the significance of success and failure, and a sec- 
ond study was then initiated to determine a rate of success and failure.

The determination of an availability rate would allow the library administration to know if the books not available were an insignificant proportion of those sought, or if they represented a major proportion and a possible service deficiency. To achieve a rate of availability, the second study required that, in addition to the number of titles not found, a measure of the actual number of titles sought should be determined.

The questionnaire had to be changed to accomplish the latter measure. The original questionnaire required some extra effort on the part of the patrons to record information that they might not originally have recorded, such as the author and title. No return rate was kept on the first questionnaire, but estimates placed it at less than 25 percent. The new design sought to make the questionnaire simple to complete. What evolved was more of a worksheet for the patron to use at the card catalog, and its use placed the burden of effort on the investigators rather than the patrons. The individual library users were merely asked to record the call number from the catalog onto the worksheet instead of their own paper. Beside each block for the call number was a space for the patrons to make a check mark for those books they could not find on the shelf.

The revised questionnaire was tested during the late summer of 1976 and then modified somewhat in wording and spacing. (See figure 1.) Initially, the study was intended to determine to what extent materials that were unavailable at the undergraduate library could be found in the main library. Returned questionnaires had to be processed in both libraries. After two weeks this study proved too ambitious for two investigators and was abandoned. During the winter quarter 1977 the study was reassessed, and the objectives were simplified to include the determination of an availability rate for books on the shelves of the undergraduate library only.

\section{METHODOLOGY OF Final StUdy}

The success of the study depended to a great extent on distributing the question- naires to as many library patrons as possible. It had been determined from the pilot study that the rate of return was highest when the worksheets were handed out and the study was explained to each patron. A speech was prepared incorporating an explanation of the study and how it would benefit the patron. The exact speech was not recited, but the main points were included in the explanation to each patron as individual worksheets were distributed. The plea was made to return the forms, regardless of success or failure, so that the information could be used to improve library services.

Return boxes were placed at each exit turnstile so that forms could be dropped off as the patron left the library. The location of the return boxes further reduced the inconvenience to the patron. Worksheets were distributed during the morning, noon, and afternoon regularly by both investigators. No records of time were kept, but it was estimated that two hours were spent distributing the questionnaire daily.

Library science students who worked as student assistants were able to hand out some worksheets at night. Also, a small number of worksheets were distributed at some time on four weekends to include those users in the sample. An arbitrary figure of 500 usable forms was set as the target response, with seven weeks allowed to collect the information. The goal was reached before the time had elapsed.

The timing of the processing of worksheets was crucial to the study. Each worksheet was picked up within two to four hours of return except those distributed at night, which were picked up the following morning. The forms contained two basic types of information: (1) a call number for each title the patron sought and (2) a check mark for each call number that was not located on the shelf.

Each call number with a check mark was checked against the shelflist to determine how many copies of the title were supposed to be in the undergraduate library. The call numbers were then searched against the circulation file to determine if the volumes were checked out, on reserve, or in some other known status. Those copies that were not found in the circulation file were then 


\section{HORKSHETT}

Use this free scratch paper. Return completed worksheet to the check-out desk or an exit, so that we can work to Improve library services.

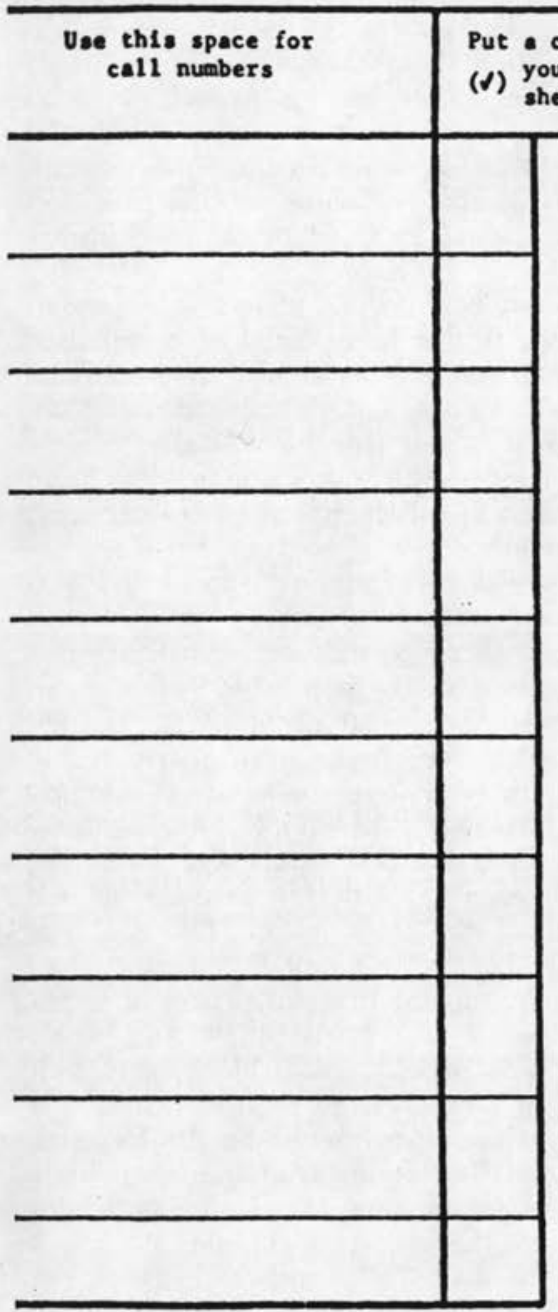

(Need more space? Use the back.)
List anything you could not find in the Undergraduate Library card catalog:
If you falled to locate something, elther in the card catalog or on the shelf, did you Aak a librarian for help.

Plan to go to another library. Look for alternate books or topics. Give up on this search.

Fig. 1

Questionnaire Used for Availability Study 
searched on the shelf to determine if there had been a patron error.

After a twenty-four-hour period, all copies of books not initially accounted for were rechecked both in the circulation file and on the shelf. At this point all books that had not yet been located were labeled unaccounted for.

\section{FINDINGS}

The total number of forms distributed in a five-week period was 1,010, and 532 of those were returned. The number of usable forms returned was 503 , or 49.5 percent of the 1,010 that were distributed. Compared to the previous study and the pilot study, the 50-percent return rate was judged very successful by the investigators. This rate was probably due to the personal contact made when handing out the forms, the simplicity of completing the form, and the prominently displayed return boxes.

A breakdown of the findings for those titles that were listed on the worksheets is presented in table 1 . The number of titles searched on 503 worksheets was 2,375 , or an average of 4.72 titles per worksheet. Users found, 1,278 titles, of the 2,375 searched, available in the library. The success rate then was 53.8 percent, which follows closely the findings of those studies discussed earlier where the average rate of success fell somewhere in the range of $\mathbf{5 0}$ percent to 60 percent.

The number of titles that could not be located by the users was 1,097 , or 46.2 percent of the total number searched. It is significant to note, however, that although 46.2 percent of the titles were not found, only 34.9 percent were actually not available in the library at the time they were searched. Approximately 11 percent of the 1,097 books that could not be located were on reserve, and about 14 percent were actually on the shelf in their correct place. This means that user error and inability to identify titles on reserve were responsible for nearly one-quarter of the failures.

The number of titles that actually were not available somewhere in the undergraduate library was 828 . Taking into consideration those titles that had multiple copies, the total number of volumes not in the library when needed was 1,025 . Table 2 shows the reasons those books were not available.

By far the most predominant reason for unavailability was that the books were in circulation. The next highest category of unavailable materials was the 20 percent that were unaccounted for and assumed stolen or misshelved. Nine months later a follow-up search of the 208 books that were unaccounted for revealed that 188 were.still missing, and 20 had reappeared on the shelves.

\section{RECOMMENDATIONS}

It was possible to take some action on the results of both availability studies immediately. Copies of those titles that had been categorized as unaccounted for were searched and declared officially missing so that replacement decisions could be made. After the first study in 1976, the undergraduate library administration initiated an inventory of the collection so that missing books could be accounted for and dis-

TABLE 1

FINDINGS FOR TITLES LISTED ON WORKSHEETS

\begin{tabular}{|c|c|}
\hline Availability of Titles & Number \\
\hline Number of titles searched by patron ( 4.72 titles per returned form) & 2,375 \\
\hline $\begin{array}{l}\text { Number of titles found on the shelf }(53.8 \% \text { of titles searched were found on the } \\
\text { shelf) }\end{array}$ & 1,278 \\
\hline $\begin{array}{l}\text { Number of titles not found on the shelf }(46.2 \% \text { of titles searched were not found } \\
\text { on the shelf) }\end{array}$ & 1,097 \\
\hline $\begin{array}{l}\text { Number of titles not found that were on reserve }(10.7 \% \text { of the titles not found } \\
\text { were on reserve) }\end{array}$ & 117 \\
\hline $\begin{array}{l}\text { Number of titles not found that were actually on the shelf (13.9\% of titles not } \\
\text { found were actually on the shelf) }\end{array}$ & 152 \\
\hline $\begin{array}{l}\text { Total number of titles actually not available ( } 34.9 \% \text { of titles searched were actually } \\
\text { not available) }\end{array}$ & 828 \\
\hline
\end{tabular}


TABLE 2

Reasons Books Were Not Available

\begin{tabular}{lcc}
\hline \multicolumn{1}{c}{$\begin{array}{c}\text { Reason Not } \\
\text { Available }\end{array}$} & $\begin{array}{c}\text { No. of Copies } \\
\text { Not Available }\end{array}$ & $\begin{array}{c}\text { Percent of Total } \\
\text { Not Available }\end{array}$ \\
\hline Checked out & 729 & $71.1 \%$ \\
Unaccounted-for & 208 & $20.3 \%$ \\
Reported missing & 40 & $3.9 \%$ \\
In binding & 22 & $2.1 \%$ \\
In building use & 17 & $1.7 \%$ \\
On hold & 7 & $0.7 \%$ \\
Interlibrary loan & 2 & $0.2 \%$ \\
\hline
\end{tabular}

crepancies at the shelflist could be removed. It was also possible to note specific titles that were in sufficient demand to warrant consideration for duplication.

While the decision to duplicate titles can be based on circulation records, availability statistics have the added value of providing a more accurate measure of demand for a particular title.

Beyond the immediate action that was taken, it was possible to identify various measures that could improve the availability of library materials. As noted earlier, there were four main reasons for the 46-percent unavailability rate: (1) lack of knowledge concerning reserve materials; (2) user error; (3) books in circulation; and (4) materials unaccounted for.

Since 11 percent of the titles not found were available within the reserve collection, this seemed an ideal place to start. One possible solution could have been to place plastic jackets on catalog cards indicating that the material was in the reserve collection. However, this is an overly expensive project that would necessitate marking cards for all added entries and require constant revision.

The Hodges Undergraduate Library has an automated circulation system from which the library produces a microfiche record of reserve materials. As an alternative to the use of plastic overlays, libraries that have automated circulation systems could make computer printouts or microfiche readers available throughout the library. This measure is now being considered for implementation in the undergraduate library.

A large number of titles not found were actually on the shelf but were not located as a result of patron error or lack of understanding of the LC classification system. Li- brary instruction can improve this problem by providing some skills in understanding the classification system and the process for following up on materials that cannot be found on the shelf.

When a patron checks with circulation and finds that a book is not charged out, on reserve, or in some other known status, the explanation generally given is that the book is in use in the building or the circulation record is on that day's computer tapes. As shown by the survey results in the undergraduate library, there was a 14-percent chance that the book was on the shelf. When possible, circulation departments could immediately check the shelf and actively promote the "search and notify" service.

Books in circulation accounted for the greatest number of failures at the shelf. One could interpret that this reflects a high level of success in selecting demanded titles, but such success is of little consolation to the user who arrives after the books have been charged out. As discussed earlier, duplication is one key to increased availability. Also, some libraries have experienced an increase in availability by shortening the loan period. But, in the case of the Hodges Undergraduate Library, the two-week loan period was considered as short as would be tolerated.

An alternative could be the establishment of a core collection that would circulate for a shorter period of time, such as three days. Short-loan materials would not have to be housed in a separate collection but could be integrated with materials in the stacks. The selection of the titles in the core could be aided by circulation figures and by identification of titles and subject areas through additional availability studies. 
Twenty percent of the books that were not available could not be accounted for. Such findings from an availability study combined with inventory statistics may lend support for an automated security system. In the meantime an analysis of call numbers through an availability study can identify LC classes which should be shelf-read regularly and inventoried periodically to identify missing volumes.

\section{CONCLUSION}

The availability study we conducted provided valuable information for assessing certain aspects of service to users. Through sampling techniques the library administration was able to get an overall view of some of the problems library users were experiencing in trying to locate needed materials. In addition, it was possible to note subject areas where heavy use and loss contributed to a low availability rate. Though measures considered for improvement of our service are as yet untested, the library is at least aware of areas where improvement is warranted. In the absence of some measure of service performance, library activities can continue blissfully along in their own ignorance.

\section{REFERENCES}

1. Daniel Gore, "The View from the Top of the Tower of Babel: Prospects for Academic Library Growth in the Near Future," in Robert Koester, ed., University of Tennessee Library Lectures, 1973-1975 (Knoxville: Univ. of Tennessee, 1976), p.33-34.

2. Ibid., p. 35 .

3. Michael K. Buckland, Book Availability and the Library User (New York: Pergamon, 1975).

4. John A. Urquhart and J. L. Schofield, 'Measuring Readers' Failure at the Shelf in Three University Libraries," Journal of Documentation 28:233-41 (Sept. 1972). For a report of an earlier availability study done by Urquhart and Schofield, which measured reasons for failure at the shelf but did not give an availability rate, see their article "Measuring
Readers' Failure at the Shelf," Journal of Documentation 27:273-86 (Dec. 1971).

5. J. L. Schofield, A. Cooper, and D. H. Waters, "Evaluation of an Academic Library's Stock Effectiveness," Journal of Librarianship 7:20727 (July 1975).

6. Richard Trueswell, "Analysis of Library User Circulation Requirements. Final Report," Jan. 1968. N.S.F. Grant GNO 435.

7. Daniel Gore, "Let Thềm Eat Cake While Reading Catalog Cards: An Essay on the Availability Problem," Library Journal 100:93-98 (Jan. 15, 1975).

8. T. Saracevic, W. M. Shaw, Jr., and P. B. Kantor, "Causes and Dynamics of User Frustration in an Academic Library," College b Research Libraries 38:7-18 (Jan. 1977). 